\title{
Experimental Investigation of Modern and Established Carotid Stents
}

\section{Experimentelle Untersuchung von modernen und etablierten Carotis-Stents}

Authors

Affiliations
C. Wissgott ${ }^{1}$, W. Schmidt ${ }^{2}$, P. Behrens ${ }^{2}$, C. Brandt ${ }^{2}$, K. P. Schmitz ${ }^{2}$, R. Andresen ${ }^{1}$

Institute of Diagnostic and Interventional Radiology/Neuroradiology, Westkuestenklinikum Heide - Academic Teaching Hospital of the Universities of Kiel, Luebeck and Hamburg, Heide

Institute for Biomedical Engineering, University of Rostock, Rostock-Warnemünde
Key words

- carotid arteries

- interventional procedures

- stents

experimental study

received 18.4.2013

accepted 16.7.2013

Bibliography

DOI http://dx.doi.org/

10.1055/s-0033-1350439

Published online: 30.8.2013

Fortschr Röntgenstr 2014; 186:

157-165 ๑ Georg Thieme

Verlag KG Stuttgart · New York

ISSN 1438-9029

\section{Correspondence \\ PD Dr. Christian Wissgott}

Institut für Diagnostische und Interventionelle Radiologie/ Neuroradiologie,

Westküstenklinikum Heide Akademisches Lehrkrankenhaus der Universitäten Kiel, Lübeck und Hamburg

Esmarchstr. 50

25746 Heide

Germany

Tel.: ++49/0 48/17 852401

Fax: ++49/0 48/17 852409

cwissgott@wkk-hei.de

\section{Zusammenfassung \\ $\nabla$}

Ziel: Design und Material bestimmen die mechanischen Eigenschaften von Stents. In vitro Kennwerte wie Radialkraft, Flexibilität und Wandanpassung unterschiedlicher Stents wurden untersucht, um Hinweise für den klinischen Einsatz zu bekommen.

Material und Methoden: Es wurden 8 Stents, hiervon 2 Hybrid-Stents mit einer Kombination von closed-/open-cell-design (Sinus Carotid RX, Cristallo Ideale), 3 closed-cell-Stents (Adapt, Carotid Wallstent, Xact Carotid) und 3 open-cell-Stents (Vivexx Carotid, Protégé Rx und Precise) mit einem Durchmesser von $8 \mathrm{~mm}$ bei einer Länge von $40 \mathrm{~mm}$, untersucht. Gemessen wurden die Radialkraft, die Biegesteifigkeit des Stentsystems und des Stents sowie der Kollapsdruck. Die Wandanpassung der Stents wurde in einem Stufen- und Kurvenmodell fluoroskopisch dokumentiert und beurteilt.

Ergebnisse: Die Biegesteifigkeit der expandierten Stents war deutlich geringer als die der Stentsysteme, wobei der Xact Carotid Stent den höchsten Wert $\left(291,1 \mathrm{~N} / \mathrm{mm}^{2}\right)$ aufwies im Gegensatz zu 31,6 bis $39,4 \mathrm{~N} / \mathrm{mm}^{2}$ für den Sinus Carotid und Cristallo Ideale. Die längenbezogene Radialkraft bei Expansion der Stents auf $7 \mathrm{~mm}$ war beim Adapt $(0,009 \mathrm{~N} / \mathrm{mm})$ am niedrigsten und beim Precise $(0,068 \mathrm{~N} / \mathrm{mm})$ am höchsten. Der Kollapsdruck ist beim Carotid Wallstent am höchsten $(0,48$ bar $)$ im Vergleich zu den übrigen Stents ( $0,1-0,2$ bar). Die beste Wandanpassung im Kurvenmodell zeigten der Precise, der Sinus Carotid Rx und der Vivexx Carotid Stent. Der Durchmessersprung von 5 auf $7 \mathrm{~mm}$ im Stufenmodell wurde am besten vom Cristallo Ideale und dem Carotid Wall Stent überwunden. Der Adapt zeigt in beiden Modellen die schlechteste Wandanpassung.

Schlussfolgerung: Designbedingt zeigen der Sinus Carotid Rx und der Cristallo Ideale die beste Wandanpassung bei vergleichbarer Radialkraft

\section{Abstract \\ $\nabla$}

Purpose: The design and material determine the mechanical properties of stents. In vitro parameters such as radial force, flexibility and wall adaptation of different stents were investigated in order to obtain evidence for clinical use.

Materials and Methods: A total of 8 stents, including 2 hybrid stents with a combination of closed/open-cell design (Sinus Carotid RX, Cristallo Ideale), 3 closed-cell stents (Adapt, Carotid Wallstent, Xact Carotid) and 3 open-cell stents (Vivexx Carotid, Protégé Rx and Precise) with a diameter of $8 \mathrm{~mm}$ and a length of $40 \mathrm{~mm}$, were investigated. The radial force, the bending stiffness of the stent system and of the stent, and the collapse pressure were measured. The wall adjustment of the stents was documented by fluoroscopy and assessed in a step and curve model.

Results: The bending stiffness of the stent systems declined significantly in the expanded state, whereby the Xact Carotid stent showed the highest value $\left(291.1 \mathrm{~N} / \mathrm{mm}^{2}\right)$ in contrast to 31.6-39.4 $\mathrm{N} / \mathrm{mm}^{2}$ for the Sinus Carotid and Cristallo Ideale. The radial force on expansion of the stents to $7 \mathrm{~mm}$ was lowest for the Adapt $(0.009 \mathrm{~N} / \mathrm{mm})$ and highest for the Precise $(0.068 \mathrm{~N} / \mathrm{mm})$. The collapse pressure was highest for the Carotid Wallstent $(0.48 \mathrm{bar})$, compared with the other stents $(0.1-0.2$ bar). The best wall adjustment in the curve model was shown by the Precise, the Sinus Carotid Rx and the Vivexx Carotid Stent. The diameter change from 5 to $7 \mathrm{~mm}$ was smoothly adapted by the Cristallo Ideale and the Carotid Wallstent. The Adapt showed poor vessel wall adaptation in both step and curved vessels.

Conclusion: As a result of their design, the Sinus Carotid Rx and the Cristallo Ideale show the best wall adjustment, with comparable radial force and high flexibility, whereby the Cristallo Ideale has the advantage that it has a closed-cell design in the middle third of the stent. The other stents 
und hoher Flexibilität, wobei der Cristallo Ideale den Vorteil hat, dass er über ein closed-cell-Design im mittleren Stentdrittel verfügt. Die übrigen Stents sind im Einzelfall weiterhin zu berücksichtigen.

Kernaussagen: Die Untersuchung der Carotis-Stents liefert eine objektive Vergleichbarkeit der mechanischischen Eigenschaften. Hieraus können Schlussfolgerungen über die jeweilige optimale Einsatzmöglichkeiten der Stents gezogen werden. Die HybridStents zeigen dabei ausgewogene Eigenschaften für eine breite Anwendungsmöglichkeit. should be taken into consideration with their specifications in individual cases.

Key Points: The investigation of carotid stents provides an objective comparison of mechanical properties. Conclusions about the respective optimum uses of stents can be drawn from this. The hybrid stents show a good balance of properties for wide applicability.

Citation Format:

- Wissgott C, Schmidt W, Behrens P et al. Experimental Investigation of Modern and Established Carotid Stents. Fortschr Röntgenstr 2014; 186: 157-165

\section{Introduction}

$\nabla$

The introduction of stent-assisted angioplasty of the extracranial internal carotid artery (ICA) has changed and expanded the options available for treating arteriosclerotic carotid stenoses [1, 2]. Although carotid endarterectomy (CEA) is still considered the gold standard in the therapy of carotid stenoses [3, 4], the implantation of carotid stents offers a valuable alternative in the prevention of strokes, since this method is less invasive and many surgical complications can be avoided $[5,6]$.

Particular attention is focused on the stents used, whose design and materials are constantly being enhanced. The balloon-expandable stents first used in 1995 had the disadvantage of low flexibility and a relatively high rate of stent collapse [7].

Therefore, self-expanding stents are exclusively used today, whereby their mechanical behavior is not only determined by the difference between open-cell and closed-cell design but also by the material used [8]. Analysis of the data available from clinical studies does not yield a clear advantage for the open-cell or closed-cell design, but there are trends that support recommendations of certain stents for specific lesion morphologies [9].

The ideal stent should reliably cover the plaque and at the same time display good wall adjustment. For this purpose, the stent must have a certain flexibility and radial force [10].

In order to achieve better comparability of established carotid stents and modern hybrid stents that have a combination of closed and open-cell design, all of the stents in this study were to be tested under the same conditions with regard to bending stiffness, radial force and collapse pressure as well as, in particular, wall adjustment in the step and curve model. These methods are well established and have already been used in various investigations on peripheral self-expanding stents [11, 12]. The experimental data gained are then to be used to make recommendations for the respective stents in routine clinical application.

\section{Materials and Methods}

The study included eight stent systems: OptiMed Sinus Carotid $\mathrm{RX}$, Invatec Cristallo Ideale, Boston Scientific Adapt, Boston Scientific Wallstent, BARD Vivexx Carotid Stent, Abbott Xact Carotid Stent, ev3 Protégé RX and CORDIS Precise. All stents are indicated for carotid stenting in vessel diameters as listed in 0 Table 1. The nominal diameters were in the range of $8-9 \mathrm{~mm}$ with a length of $30-40 \mathrm{~mm}$. Due to the specific design of the Wallstent, its length is indicated as ranging from $31-49 \mathrm{~mm}$ at vessel diameters from $10-8 \mathrm{~mm}$, respectively.

All of the included stents represent state-of-the-art technology for self-expanding carotid stents, independently of their actual date of introduction.

An overview of the design principles is given in $\bullet$ Fig. 1.

Typical modular designs consisting of corrugated ring segments connected in different ways to form the entire stent body are found in the Vivexx, Protégé RX, Sinus Carotid RX and Precise stents. The Carotid Wallstent shows the known woven filament structure. A classic closed-cell design is seen in the ADAPT stent. Remarkable is the non-circular design principle which is formed by a self-expanding rolled Nitinol sheet (see additional cross-sectional view, $\bullet$ Fig. 1). The stent is intended for use at vessel diameters varying from $4-9 \mathrm{~mm}$. Another specialty is offered by the Xact Carotid and Cristallo Ideale stents, where the cell design changes from proximal to distal from closed-cell to more opencell designs. In these cases, a change in mechanical properties can be expected along the longitudinal axis of the stents.

The stents were evaluated for bending stiffness on the stent delivery system (SDS) and in the expanded state, both freely deployed and expanded in a 7-mm vessel model. In addition, the radial force as a function of expansion diameter, the collapse pressure as the measure of radial support function and the change in length from mounted to expanded state were examined. The adaptation to changing vessel geometry such as diameter steps or tortuous vessels is also documented.

\begin{tabular}{|llll}
\hline no. & test sample & nominal dimension & indicated vessel diameter \\
\hline 1 & Optimed Sinus Carotid RX 8/40 & $8 \times 40 \mathrm{~mm}$ & \\
\hline 2 & Invatec Cristallo Ideale $9 / 40$ & $9 \times 40 \mathrm{~mm}$ & $6.5-8 \mathrm{~mm}$ \\
\hline 3 & Boston Scientific Adapt $4-9 / 40$ & $4-9 \times 40 \mathrm{~mm}$ & \\
\hline 4 & Boston Scientific Carotid Wallstent Monorail $10 / 31$ & $10 \times 31 \mathrm{~mm}$ & $9 \mathrm{~mm}$ \\
\hline & & $9 \times 40 \mathrm{~mm}$ & \\
\hline 5 & BARD Vivexx Carotid Stent $8 / 40$ & $8 \times 49 \mathrm{~mm}$ & $6.0-7.0 \mathrm{~mm}$ \\
\hline 6 & Abbott Xact Carotid Stent $8 / 30$ & $8 \times 40 \mathrm{~mm}$ & $6.4-7.3 \mathrm{~mm}$ \\
\hline 7 & ev3 PROTÉGÉ Rx 8/40 & $8 \times 30 \mathrm{~mm}$ & $6.5-7.5 \mathrm{~mm}$ \\
\hline 8 & CORDIS Precise & $8 \times 40 \mathrm{~mm}$ & $6.0-7.0 \mathrm{~mm}$ \\
\hline
\end{tabular}

Table 1 Investigated carotid stents - dimensions and indicated vessel diameters.

Tab. 1 Maße und indizierte Gefäßgröße der untersuchten Carotisstents. 


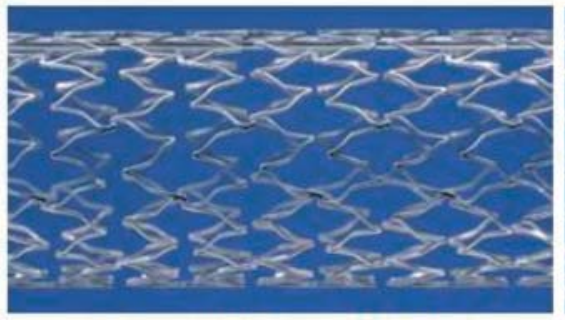

Optimed Sinus Carotid RX 8/40

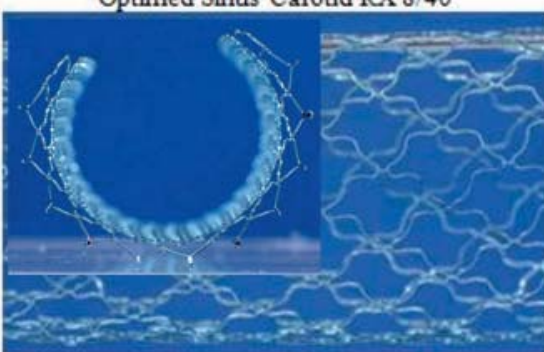

Boston Scientific Adapt 4-9/40, small image: central cross section

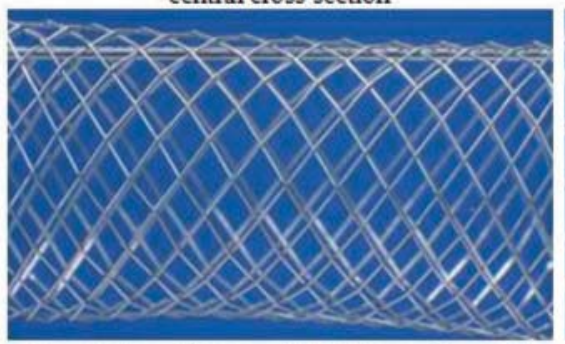

Boston Scientific Carotid Wallstent Monorail $10 / 31$

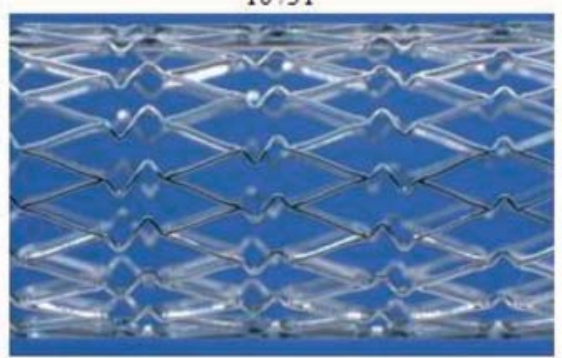

Abbott Xact Carotid Stent $8 / 30$

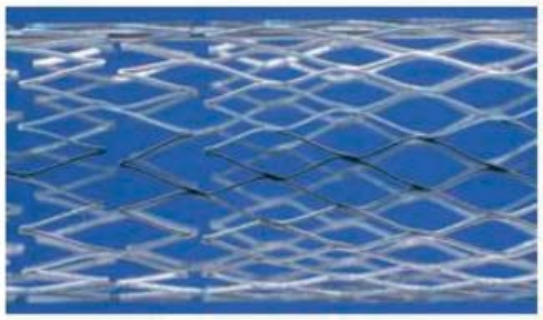

Invatec Cristallo Ideale 9/40

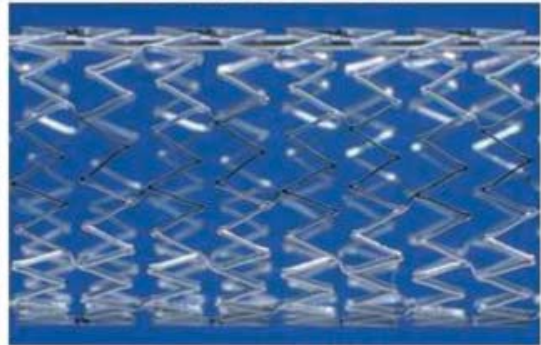

Cordis PRECISE Stent $8 / 40$

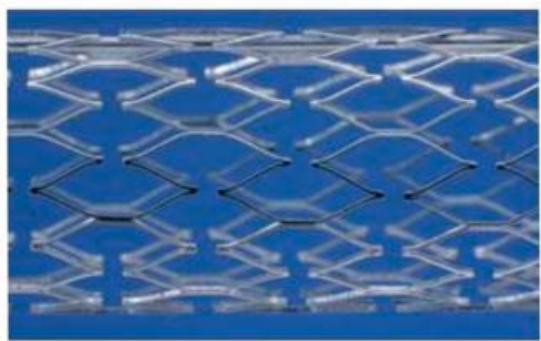

BARD Vivexx Carotid Stent $8 / 40$

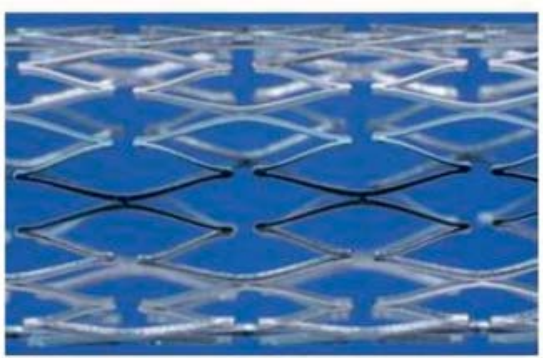

ev3 PROTÉGÉ Rx 8/40
Fig. 1 Stent structure of fully expanded test samples (detail). The small picture of the Adapt stent shows the non-circular design of the rolled Nitinol sheet.

Abb.1 Detaillierte Darstellung der Stentstruktur der untersuchten Stents im expandiertem Zustand. Im kleinen Bild des Adapt-Stent ist zu erkennen, dass es sich um eine nicht zirkulär geschlossene Struktur des Nitinol-Blattes handelt.
Most of the test methods have been presented previously for use in cardiovascular as well as peripheral balloon-expandable and self-expandable stent systems and stents [11 - 14].

\section{Bending stiffness/flexibility}

The flexibility of mounted and expanded stents was measured with one side of the test object held in place with a clamp, resulting in a free bending length of $1=12 \mathrm{~mm}$. The deflection force was measured up to a maximum bending deformation of $0.5 \mathrm{~mm}$. The recorded force distance curve describes the spring modulus of the test object for bending. Bending stiffness was calculated taking the mean value of force and related deflection using the equation

$$
\begin{aligned}
& d=\frac{F \cdot I^{3}}{3 E I} \\
& E I=\frac{F \cdot I^{3}}{3 d}
\end{aligned}
$$

which is based on the beam theory. The measurements were performed 3 times per test sample and direction to obtain an averaged value for bending stiffness. Taking into account possibly asymmetric structures of the test samples, bending stiffness was measured in 5 directions around the circumference and then averaged.

The two stents with a changing cell structure along their axes were investigated by measuring the flexibility in different longitudinal positions. Thus, the Xact stent was measured while fixed at the distal or proximal ends ( $\bullet$ Fig. 2). The same principle was applied to the Cristallo Ideale stent with fixing a) at a central position and b) near the stent end. The aim was to see whether and to what extent the structure influences the stiffness.

\section{Radial force}

The radial force during expansion and compression was measured using a test arrangement as described in [12]. The distance of the prismatic clamping supports and the resulting force during stent expansion and compression as a function of the expansion 
1.

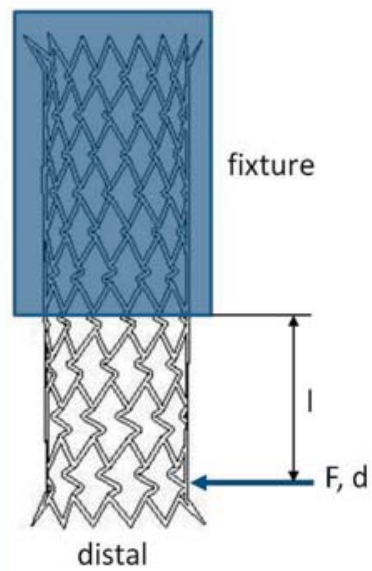

2.

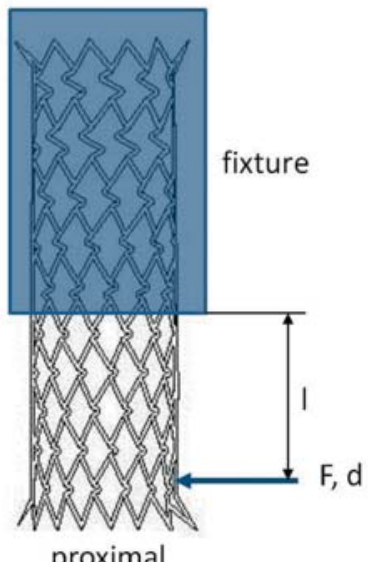

proximal
Fig. 2 Measurement of bending stiffness of the expanded Xact stent, I $=12 \mathrm{~mm}, \mathrm{dmax}=300 \mu \mathrm{m}$.

Abb. 2 Messung der Biegesteifigkeit des Xact-stents im expandiertem Zustand, I= $12 \mathrm{~mm}$, dmax $=300 \mu \mathrm{m}$.

diameter was measured by a universal test machine (Zwick BZ2,5/TN1S). The inner dimensions of the clamping supports were $5 \mathrm{~mm}$, which was $1 \mathrm{~mm}$ less than the smallest vessel diameter for which the investigated stents are intended to be used. The resulting force distance curves were used to compare the radial force of each stent at the distinctive diameter of $7 \mathrm{~mm}$, which is at the upper diameter range for most of the investigated stents. This test was performed in a $37^{\circ} \mathrm{C}$ atmosphere.

The test was modified by measuring the radial force using small blades instead of long prismatic clamps. Thus, a focally acting radial force could be obtained. The purpose was to differentiate between different zones of the three stents with non-uniform structure along their axis (closed-cell end segments: Sinus Carotid RX, closed-cell central section: Cristallo Ideale, and closed to open-cell transition from proximal to distal side: Xact). The remaining stents were measured in a central section for comparison of radial forces.

\section{Stent length}

Stent length was measured while mounted on the delivery system and after stent release in the completely expanded state, in order to assess the change in stent length. In the case of the Xact Carotid stent, the stent length as mounted on the SDS was determined by X-ray imaging, because the outer shaft of the SDS was not sufficiently translucent for optical methods.

\section{Support function/collapse pressure}

A hydraulic radial load was applied to each stent after insertion into a thin and flexible polyurethane test tube. The wall thickness of the test tube is about 100 micron and does not provide a support function, but acts as a membrane separating the inner lumen of the stent from the surrounding pressure. The tube with the stent was placed in a pressure chamber with pressure increasing in steps of 0.05 bar until the cross-section of the stent was equal to or less than $50 \%$ of its initial state. This pressure was noted as the collapse pressure. External pressure above this pressure would lead to a rapid decrease in cross-sectional area and thus worsening flow conditions.

Vessel wall adaptation was assessed after implanting the stents in rigid but optically transparent tubes. Two models were used: a) A double bent tortuous vessel model with an inner diameter of a constant $7 \mathrm{~mm}$ and b) a vessel model with a diameter step from 5 to $7 \mathrm{~mm}$. Fluoroscopic images of each stent were taken in both configurations (Micro-CT, Type SkyScan 1172, SkaYcan, Belgium). The imaging conditions were maximum field of view $(80 \times 100 \mathrm{~mm})$ and $80 \mathrm{kV}$ with a $100 \mu \mathrm{A}$ current. A $0.5-\mathrm{mm}$ aluminum filter was used for optimum image contrast of the stents as well as the less radiopaque vessel models.

\section{Results \\ $\nabla$}

A comparative graph shows the measured bending stiffness of the SDS and expanded stents ( $\mathbf{F i g} . \mathbf{3}$ ).

The most flexible SDS was measured for the Sinus Carotid RX and the Adapt stent systems. The Carotid Wallstent had by far the stiffest SDS. In all cases, the flexibility of the freely expanded stents was higher than that of the SDS with mounted stent. The most flexible stents were the Sinus Carotid RX, Precise, Vivexx Carotid and Cristallo Ideale ( 31.6 to $39.4 \mathrm{~N} / \mathrm{mm}^{2}$ ).

Due to the rolled sheet design of the Adapt stent, the flexibility of the expanded stent depended strongly on the direction of stent deflection. The stiffness ranged from 64.3 to $251.3 \mathrm{~N} / \mathrm{mm}^{2}$.

The mean stiffness of the Xact was highest $\left(291.1 \mathrm{~N} / \mathrm{mm}^{2}\right)$, but also differed measurably between the distal and the proximal end ( 245.8 to $336.4 \mathrm{~N} / \mathrm{mm}^{2}$ ). A similar effect was seen for the Cristallo Ideale stent, where the midsection was markedly stiffer $\left(97.2 \mathrm{~N} / \mathrm{mm}^{2}\right)$ than at both the proximal and distal end sections $\left(20.8 \mathrm{~N} / \mathrm{mm}^{2}\right)$.

Mounting the stents in test tubes caused an increase in total stiffness for all stents, with the exception of the Adapt stent. This configuration might be considered best for meeting real vessel conditions.

The length change as measured due to stent expansion is shown in Fig. 4. Almost no length change was seen in the Cristallo Ideale, while all other stents showed a more or less significant shortening. Maximum shortening was observed for the Carotid Wallstent (> $22 \%$ of its initial length) and the Adapt stent (14.6\%). The lowest radial force during stent expansion to $7 \mathrm{~mm}$ was measured in the Adapt stent, even if this stent is intended for use in large vessels of up to $9 \mathrm{~mm}$. The highest radial forces were seen in the Protégé RX and Precise stents ( $\bullet$ Fig. 5).

Focal measurements yielded radial forces that indeed depend on the structure of the related stent section ( $\bullet$ Table 2 ). Closed-cell structures, such as in the central part of the Cristallo Ideale, at the proximal end of the Xact or at both end segments of the Sinus Carotid RX stents exhibit far higher radial forces than in the more open-cell structures of the same stents. In general, the compressive forces are higher than the radial forces upon stent expansion. The support function of the stents quantified by the measured collapse pressure is compared in $\bullet$ Fig. 6. The Carotid Wallstent sustained the highest external pressure ( $<0.48 \mathrm{bar})$. Most stents collapsed at pressures of 0.10 to 0.14 bar, with the Protégé RX being the second best supportive stent in this investigation (collapse observed at 0.20 bar).

Vessel wall adaptation in the two vascular models is demonstrated in $\bullet$ Fig. 7 for the double bent vessel and $\bullet$ Fig. 8 for the diameter step. 


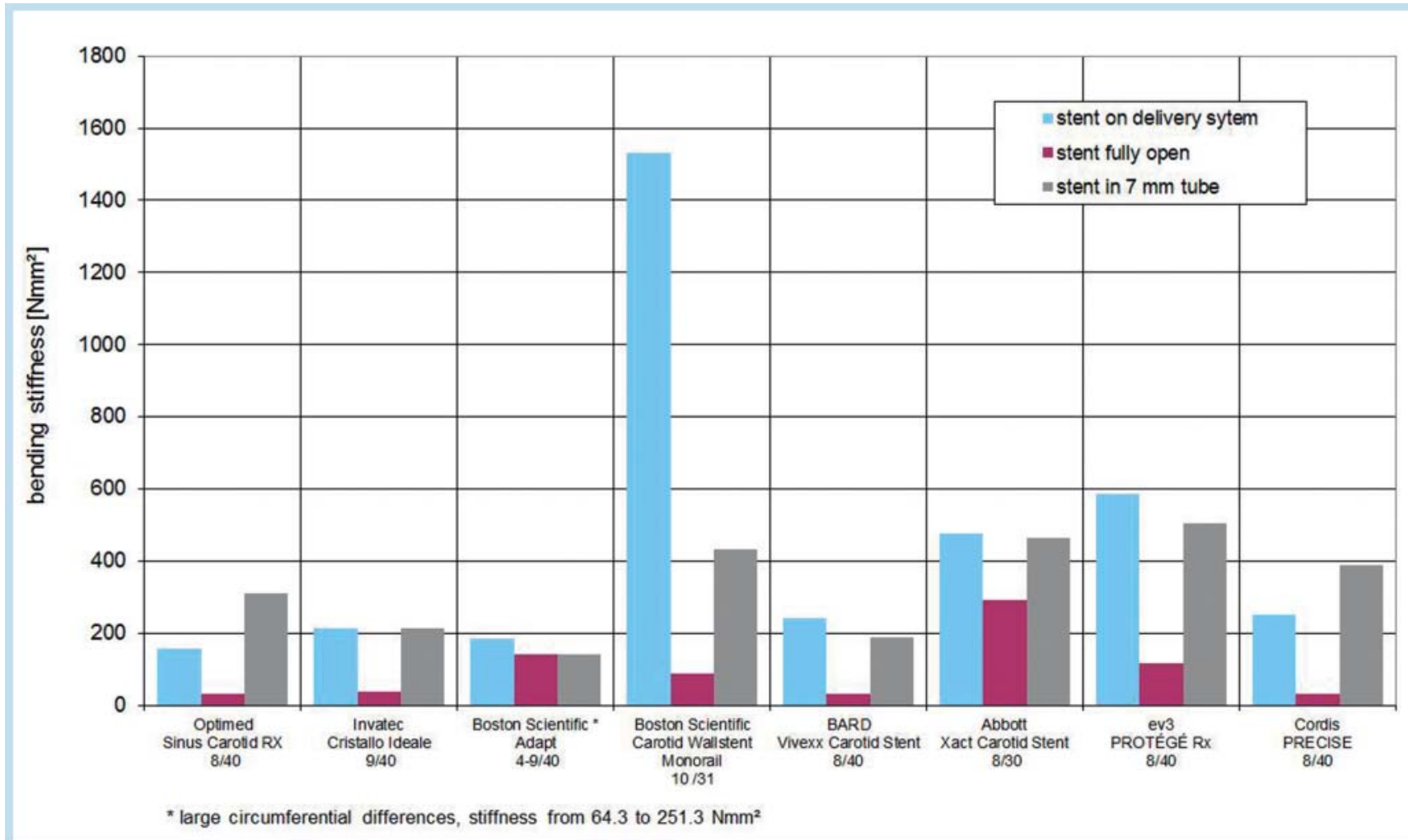

Fig. 3 Flexural (bending) stiffness of stents on delivery system and expanded stents.

Abb. 3 Biegesteifigkeit der Stents auf dem Katheter sowie im expandierten Zustand.

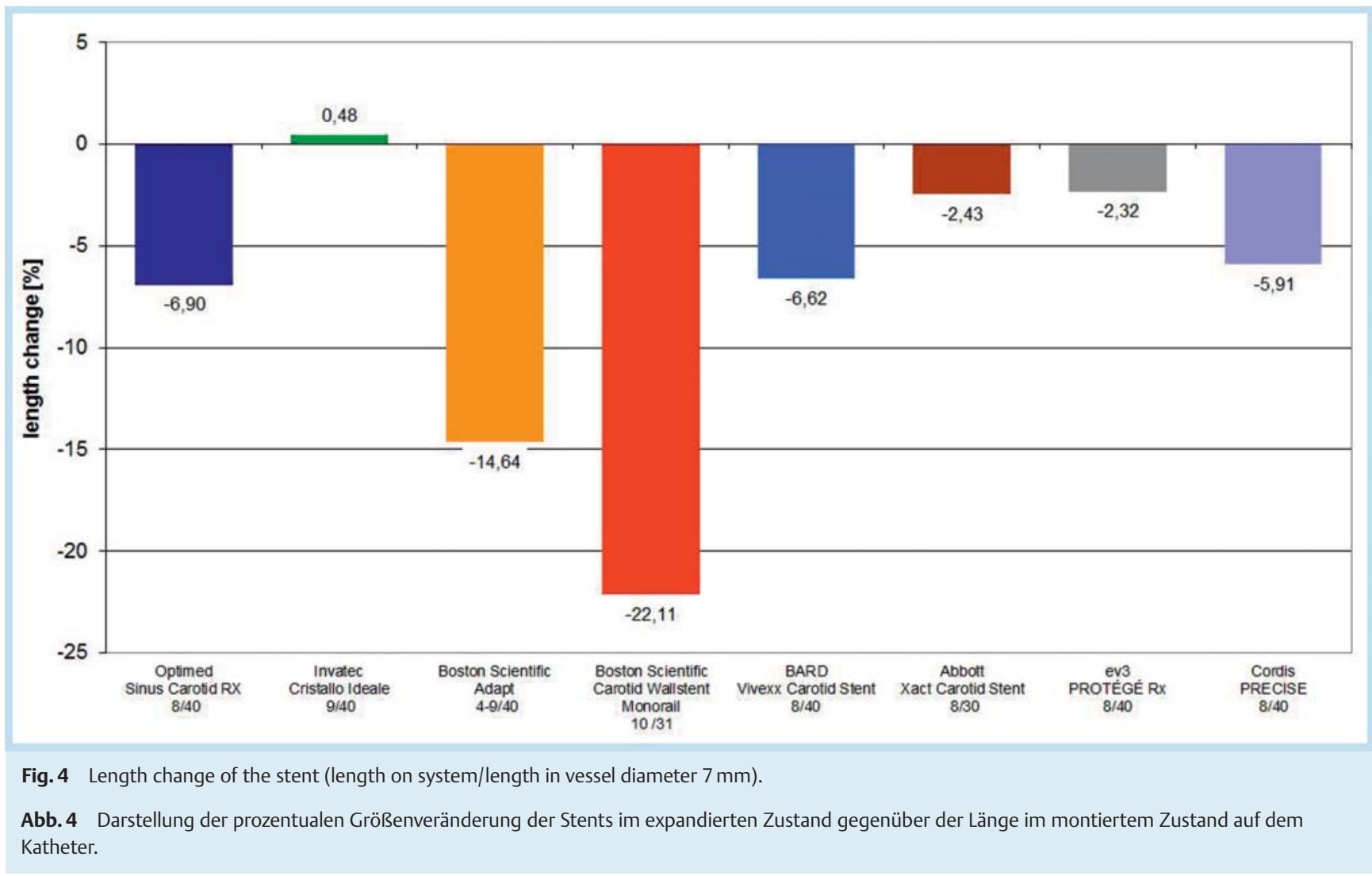




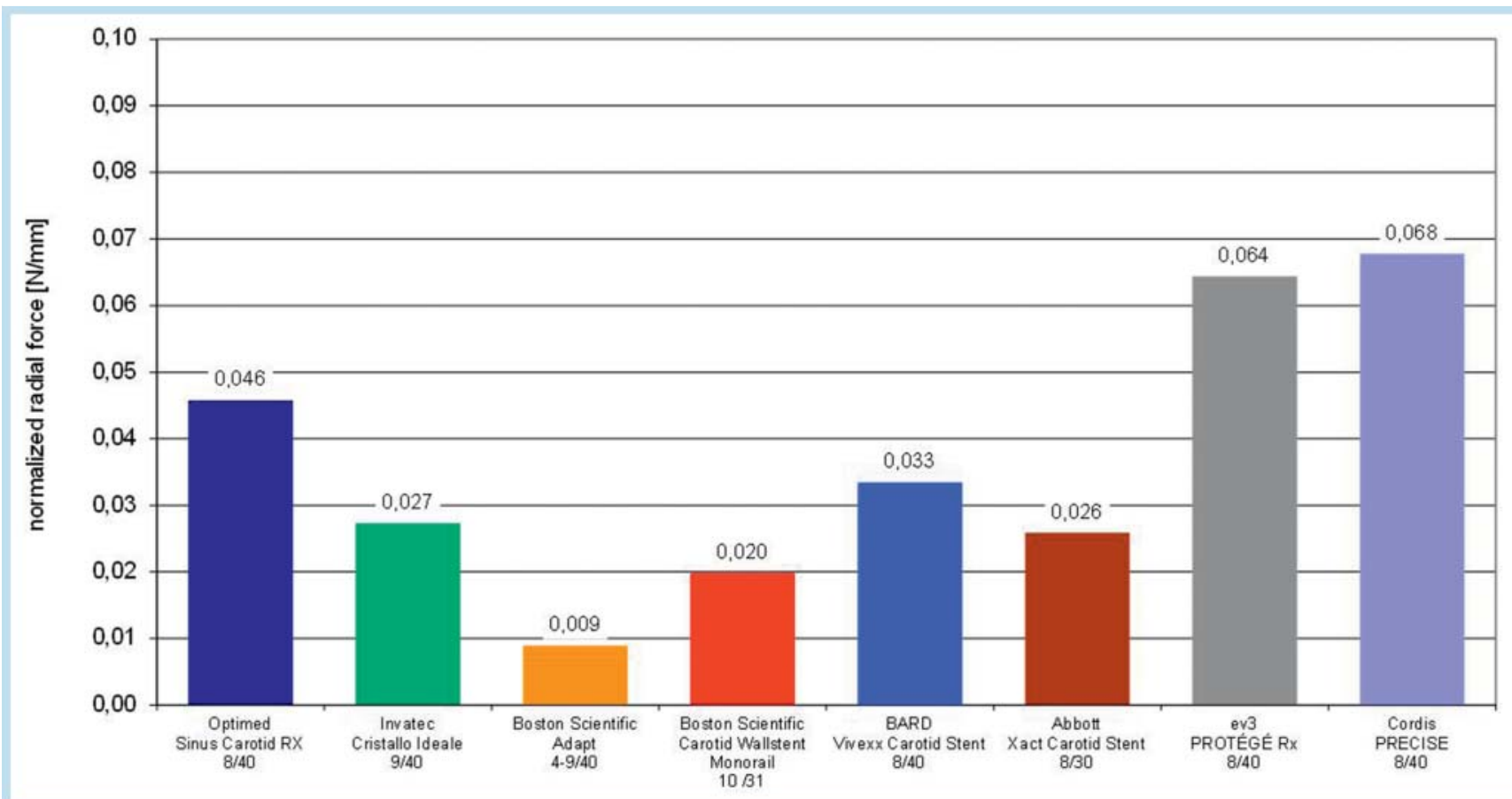

Fig. 5 Comparison of radial force at a vessel diameter of $7 \mathrm{~mm}$, normalized by actual stent length.

Abb. 5 Vergleich der Radialkraft bei einem Durchmesser von $7 \mathrm{~mm}$.

Table 2 Focal radial forces during stent compression and expansion.

Tab. 2 Fokale Radialkraft während Stentkompression und -expansion.

\begin{tabular}{|c|c|c|c|c|c|c|c|c|c|}
\hline & \multicolumn{3}{|c|}{$\begin{array}{l}\text { radial force @ } d=7 \mathrm{~mm} \\
\text { (compression) }[\mathrm{N}]\end{array}$} & \multicolumn{3}{|c|}{$\begin{array}{l}\text { radial force @ } \mathrm{d}=7 \mathrm{~mm} \\
\text { (expansion) }[\mathrm{N}]\end{array}$} & \multicolumn{3}{|c|}{$\begin{array}{l}\text { radial force @ } d=5 \mathrm{~mm} \\
\text { (compression = expansion) }[\mathrm{N}]\end{array}$} \\
\hline & distal & central & proximal & distal & central & proximal & distal & central & proximal \\
\hline Sinus Carotid RX & 1.26 & 0.71 & 1.17 & 0.59 & 0.33 & 0.52 & 2.20 & 1.31 & 2.09 \\
\hline Cristallo Ideale & 0.51 & 1.47 & 0.52 & 0.22 & 0.69 & 0.20 & 0.83 & 2.11 & 0.79 \\
\hline Carotid Wallstent Monorail & & 0.53 & & & 0.27 & & & 0.85 & \\
\hline Vivexx Carotid Stent & & 0.60 & & & 0.27 & & & 1.02 & \\
\hline Xact Carotid Stent & 0.37 & 0.45 & 0.51 & 0.14 & 0.24 & 0.21 & 1.07 & 1.77 & 1.72 \\
\hline PROTÉGÉ Rx & & 1.33 & & & 0.69 & & & 2.27 & \\
\hline PRECISE & & 0.91 & & & 0.36 & & & 1.39 & \\
\hline
\end{tabular}

Comparably good adaptation in the double bent model was seen for the Sinus Carotid RX, Vivexx Carotid, Protégé RX and Precise stents. In the case of the Cristallo Ideale, it can be seen that the wall adaptation depends on the related stent section. The closed-cell section showed limited adaptation because of its high stiffness, while the open-cell part adapted much better. Worse adaptation accompanied by a significant lumen reduction was observed in the Adapt, Carotid Wallstent and Xact Carotid stents.

The Adapt, Xact and Carotid Wallstent stents did not adapt well to the diameter step, but showed a smooth transition. The modular stents followed the diameter reduction more closely, depending on the segment lengths. The best wall adaptation was observed in the Precise, Cristallo Ideale and Protégé RX stents, with only small differences between the individual stent designs.

\section{Discussion}

The treatment of carotid stenoses by means of stent-assisted carotid angioplasty involves mechanical break-up and displacement of the arteriosclerotic plaque material. Therefore, the design and the material of the carotid stents take on considerable importance in achieving a good long-term clinical outcome. Requirements placed on the stent are reliable plaque coverage, accompanied by good wall adjustment through high flexibility and radial force $[15,16]$. The importance of these requirements on a carotid stent is highlighted by a study that shows that most neurological complications do not occur until the post-procedural phase [17].

In order to achieve an objective comparison of the available carotid stents, we investigated both the standard open-cell stents (Precise, Protégé, Vivexx) and closed-cell stents (Xact, Carotid Wall Stent, Adapt) and especially the modern hybrid stents (Cris- 


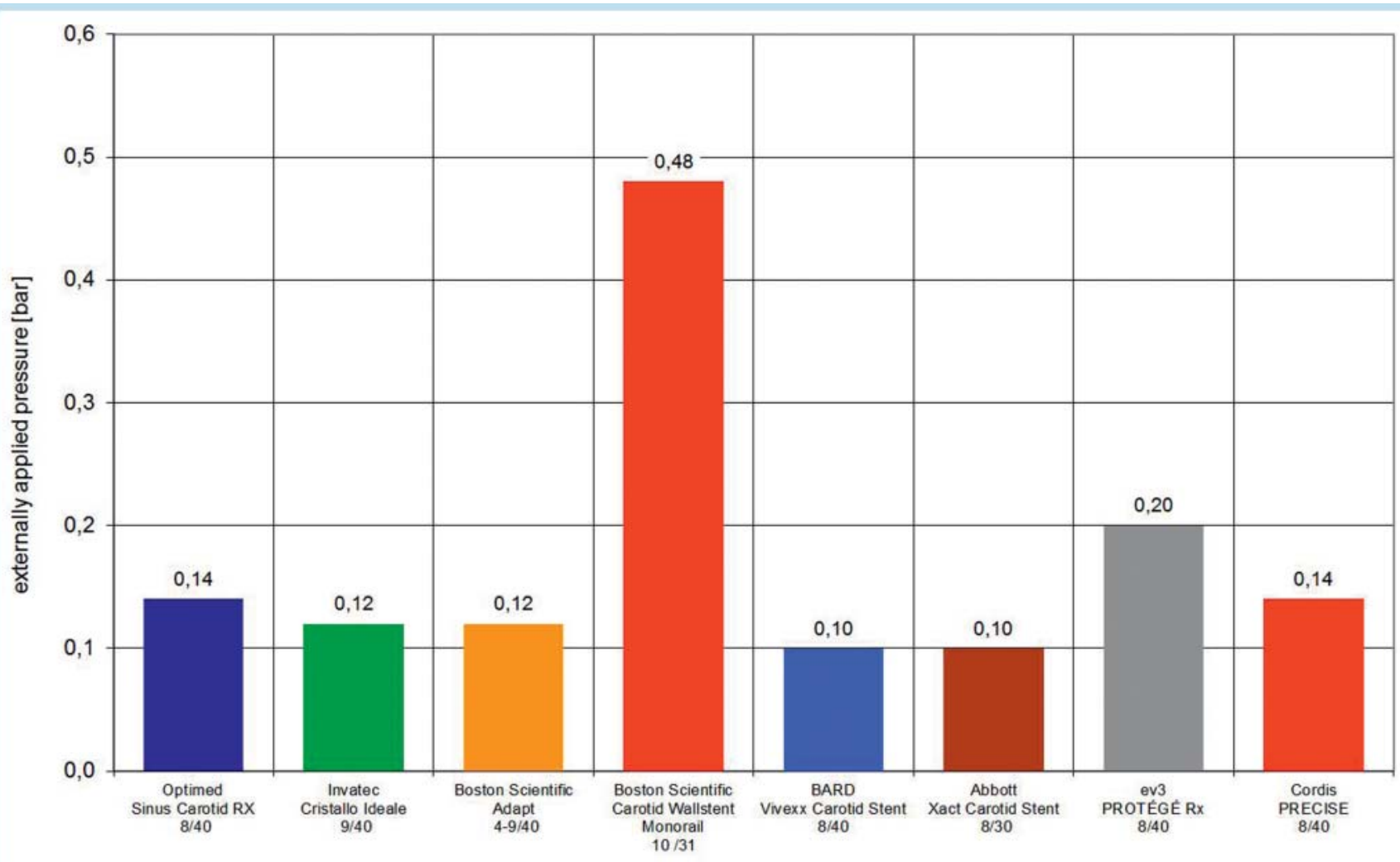

Fig. 6 Collapse pressure at a vessel diameter of $7 \mathrm{~mm}$.

Abb. 6 Kollapsdruck bei einem Durchmesser von $7 \mathrm{~mm}$.

tallo Ideale, Sinus Carotid). Of particular interest was the behavior of the hybrid stents with regard to their contrary structure. The investigation of the bending stiffness of the expanded showed that the "closed-cell" stents (139.9-291.1 $\left.\mathrm{Nmm}^{2}\right)$ have the lowest flexibility, in contrast to the open-cell stents and the hybrid stents $\left(31.6-39.4 \mathrm{~N} / \mathrm{mm}^{2}\right)$. This is also confirmed by the results of Müller-Hülsbeck et al. using a different study design, who found the lowest flexibility for closed-cell stents and the best flexibility for the hybrid stent with a closed-cell design in the central section (Cristallo Ideale), whereby the other hybrid stent was missing in this investigation [10]. In the mounted condition on the delivery system, the hybrid stents and the Adapt were the most flexible, while the Carotid Wallstent had the stiffest SDS $\left(1530 \mathrm{~N} / \mathrm{mm}^{2}\right)$.

Apart from flexibility, radial force also plays an important role in displacing any plaque material present. The results of our measurements are consistent with the observations of another exvivo investigation with high radial forces for the open-cell stents and low radial forces for the closed-cell stents. The two hybrid stents lie in between [10]. The differences here are certainly not exclusively attributable to the closed or open-cell principle, but also to the design of the surrounding structure. The focal measurement of the radial forces produced the highest radial stiffness in the areas of the closed cells.

In the early days of carotid stent implantation, the tendency of the balloon-expandable stents to collapse was a decisive limiting factor [18-20]. Therefore, it is now standard practice to only implant self-expanding stents, whereby there is no clear difference between the closed-cell and open-cell stents in this respect. The stents investigated here show a collapse pressure of between
0.10 and 0.14 bar. Only the Protégé RX shows a slightly higher collapse pressure at 0.20 bar. The Carotid Wallstent holds an exceptional position with a collapse pressure of 0.48 bar. This markedly higher pressure can be explained by its particular tubular mesh-graft design and the hindrance of a change in length in the vessel $[10,21]$.

It has been described repeatedly that the shortening of the stents in the expanded state compared with the non-expanded state on the delivery system can lead to problems, particularly in the case of less experienced investigators. This leads to difficulties in the exact placement of the stents, which can thus also influence the clinical results [22]. Virtually all stents show a shortening, observed most strongly in the Adapt and Carotid Wallstent, which may depend on the special design of the stent structure, with a percentage shortening of approx. $14 \%$ and $22 \%$, respectively. The Cristallo Ideale is alone in not showing any shortening, but a slight lengthening of approx. $0.48 \%$. This facilitates precise positioning of the stent, in order to cover the plaque directly in the middle with the closed-cell part of the stent.

Another decisive factor is in particular the wall adjustment of the stents with as reliable as possible a coverage of the plaque material $[17,23]$. In order to be able to make a comprehensive assessment of wall adjustment, the stents were investigated on the one hand in an angulated vascular model and on the other hand in a vascular model with a stepwise change in diameter. In the angulated vascular model, only a small wall adjustment is to be observed for the purely closed-cell stents (Xact, Adapt, Carotid Wallstent). In contrast, the open-cell stents and the hybrid stent with the open-cell part in the central section (Sinus Carotid) display very good wall adjustment. Therefore, in carotid arteries 


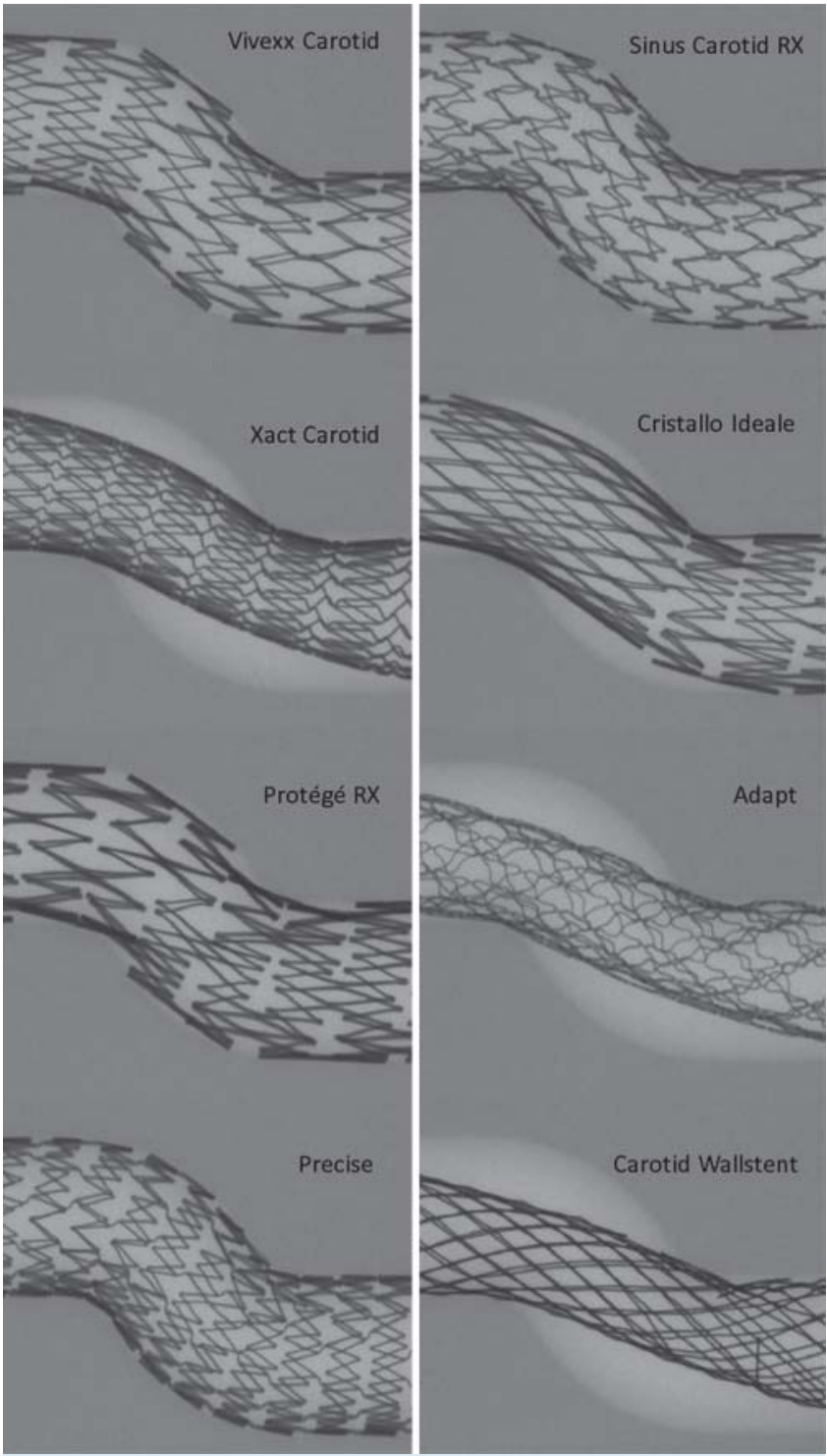

Fig. 7 Adaptation of different carotid stent types to a double bent tortuous vessel with an inner diameter of $7 \mathrm{~mm}$.

Abb.7 Wandanpassungsfähigkeit der unterschiedlichen Stents im anguliertem Gefäßmodell mit einem Durchmesser von $7 \mathrm{~mm}$.

with a deep angulation, the open-cell stents seem to be a good option. However, it is to be observed that the individual cell areas spread out and that struts project into the lumen in some cases. Such behavior has already been described in other studies and identified as a possible risk factor for an increased plaque embolization rate $[17,24]$. The hybrid stent with a closed-cell design in its central section (Cristallo Ideale) shows relatively good wall adjustment, without accompanying spreading of the cell areas [24]. Also in the step model, the Cristallo Ideale achieves harmonious adjustment to the different vessel diameters. In the open-cell stents, the problem again occurs that the cell areas spread out widely and thus do not provide for reliable plaque coverage [23]. The Carotid Wallstent and the Xact also show a relatively good adaptation to the step model.

Indirectly, conclusions about plaque penetrability can also be drawn from these observations. On the one hand, as a result of their design, closed-cell stents have better plaque coverage com-

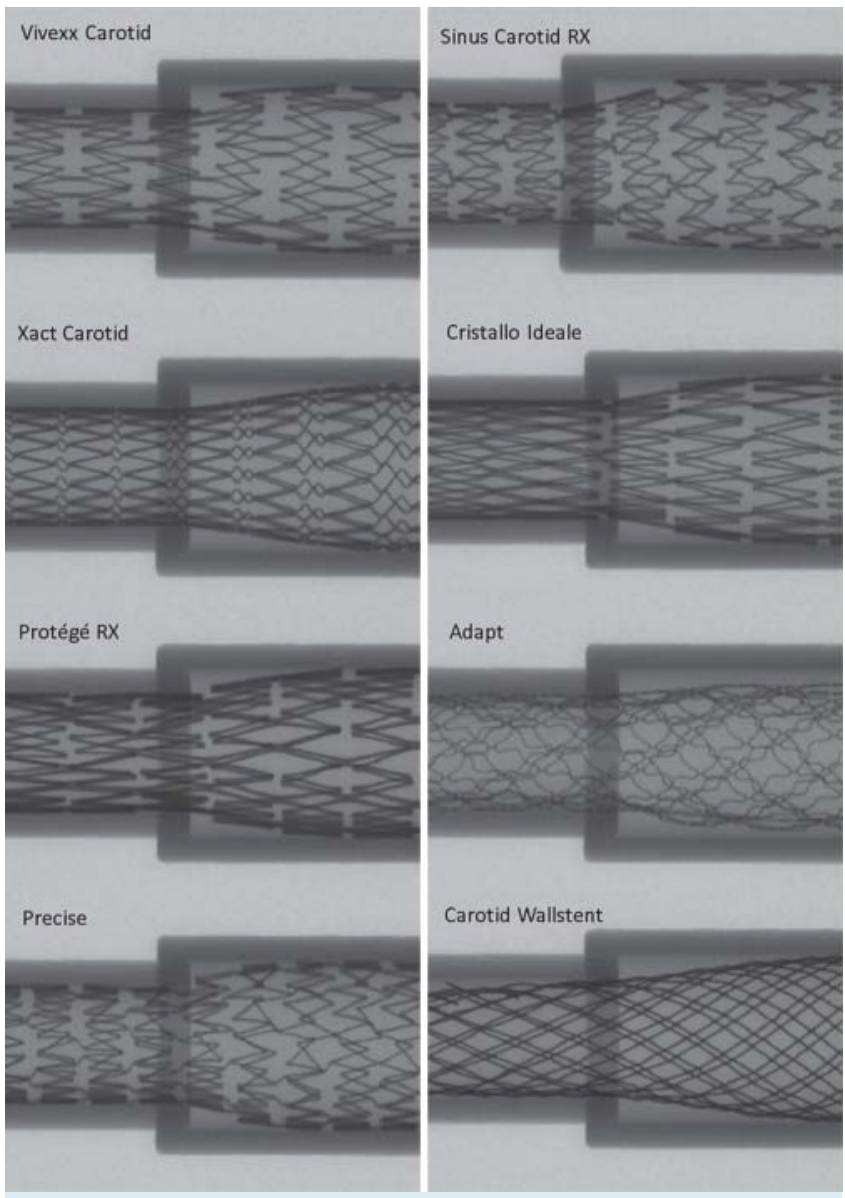

Fig. 8 Adaptation of different carotid stent types to a diameter step from an inner diameter of 5 to $7 \mathrm{~mm}$.

Abb.8 Wandanpassungsfähigkeit der Stents in einem Gefäßmodell mit Kalibersprung von $5 \mathrm{~mm}$ auf $7 \mathrm{~mm}$.

pared with the open-cell stents. Müller-Hülsbeck et al. tested the pressure required for the penetration of particles of 1.5 to $6 \mathrm{~mm}$ in their ex-vivo investigation. The hybrid stent Cristallo Ideale had the lowest particle penetration, allowing only $1.5-\mathrm{mm}$ particles to pass through. The Precise and Protégé Rx had the highest penetrability [10].

When taking into account the available clinical data, no significant differences could be determined between open-cell and closed-cell stents in the large-scale studies [9]. However, a single-center analysis showed a lower rate of neurological complications for the closed-cell stents [17]. The relatively modern hybrid stents have not yet been used in the large prospective studies. However, a prospective study with 124 patients is available for the Cristallo Ideale, with a technical success rate of $100 \%$ and a rate of neurological complications of $1.6 \%$ within 30 days, a complication rate much lower than the rates reported in other studies [25].

Also with regard to the re-stenosis rate, a significant difference between the open-cell and closed-cell stents could not be demonstrated from the literature, although again there were no data available on the hybrid stents [17].

The limitations of the present study are that these ex-vivo investigations are not directly transferable to clinical application, although the test methods are well established [11 - 14] and yield 
quantitative data that allow a relatively good transfer of the results to in-vivo use.

\section{Conclusion}

As a result of their design, the Sinus Carotid Rx and the Cristallo Ideale in the "hybrid design" show the best wall adjustment, with comparable radial force and high flexibility, and thus can also be used in the case of an axis-deviant vascular course with steps in vessel diameter, whereby the Cristallo Ideale has the advantage that it has a "closed-cell" design in the middle third of the stent and can thus reliably cover the stenosing plaque material. However, in the event of unusual vascular anatomies, the other stents should continue to be taken into consideration with their respective specifications in individual cases.

\section{Clinical relevance of the study}

$\nabla$

1. The implantation behavior is a result of the material and design.

2. Experimental tests give an objective comparison of carotid stents.

3. As a result of the tests, the hybrid stents seem to be a very good option for treating a wide range of carotid artery stenoses.

\section{References}

1 Wholey MH, Wholey M, Mathias K et al. Global experiences in cervical carotid artery stent placement. Catheter Cardiovasc Interv 2000; 50: $160-167$

2 Andresen $R$, Roth $M$, Brinckmann $W$. Ambulante primäre Stentangioplastie von symptomatischen Arteria-carotis-interna-Stenosen. Zentrabl Chir 2003; 128: 703-708

3 ExecutiveCommittee for the Asymptomatic Carotid Atherosclerosis Study. Endarterectomy for asymptomatic carotid artery stenosis. JAMA 1995; 273: 1421 - 1428

4 Ferguson GG, Eliasziw M, Barr HW et al. The North American Symptomatic Carotid Endarterectomy Trial: surgical results in 1415 patients. Stroke 1999; 30: 1729-1737

5 Endovascular versus surgical treatment in patients with carotid stenosis in the Carotid and Vertebral Artery Transluminal Angioplasty Study (CAVATAS): a randomised trial. No authors listed Lancet 2001; 357: $1729-1737$

6 Roubin GS, New G, Iyver SS et al. Immediate and late clinical outcomes of carotid artery stenting in patients with symptomatic and asympto- matic carotid artery stenosis: a 5-year prospective analysis. Circulation 2001; 100: $532-537$

7 Wholey MH, Al-Mubarak N, Wholey MH. Updated review of the global carotid artery stent registry. Catheter Cardiovasc Interv 2003; 60: 259-266

8 Carnelli D, Pennati G, Villa $T$ et al. Mechanical properties of open-cell, self expandable shape memory alloy carotid stents. Artif Organs 2011; 35: 74-80

9 Nikas DN, Kompara G, Reimers B. Carotid stents: which is the best option? J Cardiovasc Surg 2011; 52: 779-793

10 Müller-Hülsbeck S, Schäfer PJ, Charalambous N et al. Comparison of Carotid Stents: An In-Vitro Experiment Focusing on Stent Design. J Endovasc Ther 2009; 16: $168-177$

11 Wissgott C, Schmidt W, Behrens P et al. Vergleich mechanischer Eigenschaften von selbst expandierenden peripheren Stents. Fortschr Röntgenstr 2009; 181: 579-586

12 Schmidt W, Wissgott C, Behrens P et al. Performance characteristics of modern self-expanding nitinol stents indicated for SFA. Fortschr Röntgenstr 2011; 183: 818-825

13 Schmidt W, Schmitz K.-P. Devices. In: Mastering of Endovascular Techniques - A guide to excellence. (ed. P. Lanzer) Philadelphia: Lippincott William \& Wilkins; 2006: 114-135

14 Schmidt W, Andresen R, Behrens $P$ et al. Mechanische Eigenschaften peripherer Ballonexpandierbarer Stentsysteme. Fortschr. Röntgenstr 2002; 174: 1430 - 1437

15 Hong MK, Mintz GS, Lee CW et al. Incidence, mechanism, predictors, and long-term prognosis of late stent malapposition after bare-metal stent implantation. Circulation 2004; 109: 881 - 886

16 Duda SH, Wiskirchen J, Tepe G et al. Physical properties of endovascular stents: an experimental comparison. J Vasc Interv Radiol 2000; 11 : $645-654$

17 Bosiers M, de Donato G, Deloose K et al. Does free cell area influence the outcome in carotid artery stenting. Eur J Vasc Endovasc Surg 2007; 33 : $135-141$

18 Mathias K, Jager H, Hennings $S$ et al. Endoluminal treatment of internal carotid artery stenosis. World J Surg 2001; 25: 328 - 334

19 Vitek J, Roubin G, Al-Mubarek $N$ et al. Carotid artery stenting: technical considerations. Am J Neuroradiol 2000; 21: 1736-1743

20 Mathur A, Dorros G, Iyer $S$ et al. Palmaz stent compression following carotid stenting. Cath Cardiovasc Diagn 1997; 41: 137-140

21 FDA approval devices. Carotid WALLSTENT ${ }^{\circledR}$ Monorail ${ }^{\circledR}$ Endoprothesis. 24.08 2011, http://www.accessdata.fda.gov

22 Ahmadi $R$, Willfort A, Lang $W$ et al. Carotid artery stenting: effect of learning curve and intermediate-term morphological outcome. J Endovasc Ther 2001; 8: 539-546

23 Wholey MH, Finol EA. Designing the ideal stent. Endovasc Today 2007; 6: $25-34$

24 Bosiers $M$, Deloose $K$, Verbist $J$ et al. What practical factors guide the choice of stent and protection device during carotid angioplasty? Eur J Vasc Endovasc Surg 2008; 35: 637-643

25 Cremonesi A, Rubino P, Grattoni $C$ et al. Multicenter experience with a new "hybrid" carotid stent. J Endovasc Ther 2008; 15: 186-192 